\title{
Chewing Lice (Phthiraptera) Species on Wild Birds in Cappadocia Region, Turkey
}

Türkiye’nin Kapadokya Bölgesi’nndeki Yabani Kuşlarda Bulunan Ciiğneyici Bit (Phthıraptera) Türleri

\author{
Abdullah iNCi' ${ }^{1}$, Bilal DiK², Murat KiBAR ${ }^{3}$, Alparslan YILDIRIM¹', Önder DÜZLÜ ${ }^{1}$ \\ ${ }^{1}$ Department of Parasitology, Faculty of Veterinary Medicine, Erciyes University, Kayseri \\ ${ }^{2}$ Department of Parasitology, Faculty of Veterinary Medicine, Selcuk University, Konya \\ ${ }^{3}$ Department of Surgery, Faculty of Veterinary Medicine, Erciyes University, Kayseri, Turkey
}

\section{ABSTRACT}

Objective: This study was performed on 70 injured wild birds belonging to 7 different species in the Cappadocia region between 2005 and 2009. All birds were inspected for ectoparasites and 29 of 70 (41.4\%) birds were found to be infested by at least one chewing louse species. Methods: All lice were cleared in $10 \% \mathrm{KOH}$, mounted in Canada balsam on slides and identified under a light microscope.

Results: The lice were identified as Laemobothrion maximum, Craspedorrhynchus platystomus, Degeeriella fulva and Colpocephalum nanum from the long-legged buzzards (Buteo rufinus), as C. platystomus, L. maximum, D. fulva and C. nanum from the common buzzards (Buteo buteo), as D. fulva and Colpocephalum sp. from the honey buzzard (Pernis apivorus), as Colpocephalum milvi and L. maximum from the black kites (Milvus migrans), as Strigiphilus barbatus from the long-eared owl (Asio otus), as Comatomenapon elongatum from the great egret (Egretta alba) and as Colpocephalum zebra from the white stork (Ciconia ciconia).

Conclusion: Honey buzzard was found as a new host for Degeeriella fulva and Colpocephalum sp. and these lice were recorded for the first time in this study. Colpocephalum milvi from the black kite and Comatomenapon elongatum from the great egret have been reported for the first time with this study in Turkey. (Turkiye Parazitol Derg 2010; 34: 174-8)

Key Words: Chewing lice, wild birds, Cappadocia, Turkey

Received: 07.09.2010

Accepted: 01.12.2010

\section{ÖZET}

Amaç: Bu çalışma, 2005-2009 yılları arasında Kapadokya Bölgesi'nde bulunan 7 farklı türe ait 70 yabani yaralı kuş üzerinde yapılmıştır. Yöntemler: Bütün kuşlar ektoparazit yönünden muayene edilmiş ve 70 kuştan 29'unun (\%41.4) en az bir çiğneyici bit türü ile enfeste olduğu saptanmıştır. Toplanan bit örnekleri \%10'luk KOH ile saydamlaştııldıktan sonra Kanada balsamı ile lam üzerine yapıştırılmış ve ışık mikroskobu altında teşhis edilmiştir.

Bulgular: Kızıl şahinden toplanan bitler Laemobothrion maximum, Craspedorrhynchus platystomus, Degeeriella fulva ve Colpocephalum nanum, şahinden toplananlar C. platystomus, L. maximum, D. fulva ve C. nanum, arı şahininden toplananlar D. fulva ve Colpocephalum sp., kara çaylaktan toplananlar Colpocephalum milvi ve L. maximum, uzun kulaklı orman baykuşundan toplanan Strigiphilus barbatus, beyaz balıkçıldan toplanan Comatomenapon elongatum ve beyaz leylekten toplanan bit ise Colpocephalum zebra olarak teşhis edilmiştir.

Sonuç: Arı şahininin Degeeriella fulva ve Colpocephalum sp. için yeni bir konak olduğu belirlenmiş ve arı şahinindeki bu bit türleri ilk defa bu çalışma ile kayıt altına alınmıştır. Kara çaylaktan toplanan Colpocephalum milvi ve beyaz balıkçıldan toplanan Comatomenapon elongatum Türkiye'den ilk kez bu çalışma ile bildirilmektedir. (Turkiye Parazitol Derg 2010; 34: 174-8)

Anahtar Sözcükler: Çiğneyici bitler, yabani kuşlar, Kapadokya, Türkiye

Geliş Tarihi: 07.09.2010

Kabul Tarihi: 01.12.2010

This study was presented in the Fourth International Conference on Phthiraptera, 13-18 June, 2010, Urgüp, Cappadocia, Turkey Address for Correspondence/Yazışma Adresi: Dr. Abdullah İnci, Department of Parasitology, Faculty of Veterinary Medicine, Erciyes University, Kayseri, Turkey Phone: +90 3523392312 E-mail: ainci@erciyes.edu.tr doi:10.5152/tpd.2010.07 


\section{INTRODUCTION}

It is generally accepted that lice (Phthiraptera parasitic lice, Hemimetabola) are derived from the insect order Psocoptera (the so-called book lice or bark lice), and it is speculated that their origin was between the Late Carboniferous and the end of the Cretaceous era, 66-320 million years ago. The order Phthiraptera comprises four suborders, three of which (Amblycera, Ischnocera, and Rhynchophthirina) are known as chewing or biting lice and the fourth (the Anoplura) as sucking lice. Chewing lice (Phthiraptera: Amblycera, Ishnocera) are permanent obligate ectoparasites and are distributed worldwide throughout most bird families (1). Chewing lice have mandibulate mouthparts and have probably evolved on birds. They are thought to have fed initially on skin and feathers, with some groups ultimately expanding their diets to include tissue fluids and blood. Some chewing lice eventually made a transition from birds to mammals and some Ricinidae (Amblycera) have mouthparts adapted to pierce host skin (2). Living mainly on the skin, amblyceran lice may cause irritation of the skin, restlessness, overall weakening and cessation of feeding, loss of weight, inferior laying capacity, and skin lesions that may become sites of secondary infection $(3,4)$. Chewing lice living on feathers, such as ischnocerans, although causing damage to feathers, affect their hosts much less than do amblycerans (1). With regard to the economic importance of chewing lice on poultry, various aspects of their biology have been studied, such as distribution on the host body, population dynamics, geographical distribution or economic damage $(5,6)$.

The order Phthiraptera has nearly 5000 species in some 28 families and moreover, those lice have been reported from birds (7). The current knowledge on the louse fauna of birds and mammals in Turkey is quite incomplete. Up to today, a total of 109 species belonging to 50 genera of lice have been recorded from animals and humans, based on the morphological identification of these parasites. Eighty two louse species belonging to 37 genera in three families have been reported from birds in Turkey, although there are only a few studies (8-12). Eleven louse species belonging to 11 genera and 67 species belonging to 32 genera have been reported from poultry $(3,13,14)$ and wild birds $(8,9$, 11, 15-30), respectively.

The objective of this study was to identify louse species collected from injured wild birds found in the Cappadocia region.

\section{MATERIAL AND METHODS}

Between 2005 and 2009, 70 wounded wild birds including 39 long-legged buzzards (Buteo rufinus), 14 common buzzards (Buteo buteo), 7 black kites (Milvus migrans), 4 eagle-owls (Bubo bubo), 3 great egrets (Egretta alba), 1 honey buzzard (Pernis apivorus), 1 long-eared owl (Asio otus) and 1 white stork (Ciconia ciconia) which were found around the Cappadocia region were transferred to the surgery clinic of the Faculty of Veterinary Medicine, Erciyes University. All birds were inspected for ectoparasites. The manually collected lice from infested birds were transferred to vials with $70 \%$ ethyl alcohol and stored in the laboratory until the microscopic examination. At the same time the protocols for each bird species and the collected lice from all infested birds were recorded. The louse specimens were cleared in $10 \% \mathrm{KOH}$, mounted in Canada balsam on slides and identified under a light microscope.

\section{RESULTS}

During the clinical examination, a total of 65 (35 females, 23 males and 7 nymphs) louse species were found in 29 of 70 (41.4\%) birds (9 Long-legged Buzzards, 14 Common Buzzards, 2 Black Kites, 1 Great Egret, 1 Honey Buzzard, 1 Long-eared Owl and 1 White Stork). The identified louse species and their hosts were shown in Table 1. The distributions of louse species around the Cappadocia region are shown in Figure 1.

As seen in Table 1, the most prevalent louse species was determined as Degeeriella fulva (Figure 2A) at an incidence of $41.5 \%$, and this rate was followed by Laemobothrion maximum (Figure 2B) $20.0 \%$, Colpocephalum nanum (Figure 2C) 16.9\%, Craspedorrhynchus platystomus (Figure 2D) 13.8\% and the rest [Colpocephalum milvi (Figure 2E), Colpocephalum zebra (Figure 2F), Strigiphilus barbatus (Figure 2G) and Comatomenapon elongatum (Figure 2H), Colpocephalum sp. (Figure 2I, 2J)] with 1.5\%.

\section{DISCUSSION}

There are few studies on the louse species of wild birds in Turkey. The louse species collected from wild birds in Turkey are also limited (19). Up to the present, 3 louse species on wild partridges (15), 1 on the wild geese (16), 5 on the long-legged buzzards (Buteo rufinus) (17), 4 on the white stork (Ciconia ciconia) (22), 1 on the Eurasian eagle owl (Bubo bubo) (24), 2 on the ring-necked pheasants (Phasianus colchicus) $(23,29), 4$ on the starlings (Sturnus vulgaris) (28), 1 on the nightjars (Caprimulgus europaeus) (18), 1 on the black vulture (Aegypius monachus) (27), 20 on the shorebirds (Chlidonias leucopterus, Gallinago gallinago, Tringa glareola, Calidris minuta, Calidris alpina, Calidris temminckii, Philomashus pugnax) (10), 1 on the dove (Streptopelia decaocto) (20), 1 on the budgerigar (Melopsittacus undulatus) (20), 1 on the marbled duck (Marmaronetta angustirostris) (20), 3 on the mallards (Anas platyrhynchos) (8), 3 on the wild quails (Coturnix coturnix) (9) and 1 on the red-backed shrikes (Lanius collurio) (11) were reported from wild birds in Turkey. In addition, 25 birds belonging to 15 different species at the zoo in Konya were inspected for the presence of chewing-lice and 3 longlegged buzzards (Buteo rufinus), 1 imperial eagle (Aquila heliaca) and 1 marsh harrier (Circus aeruginosus) were found to be infested by chewing-lice. Craspedorrhynchus fraterculus (Eichler \& Zlotorzycka, 1975), Degeeriella aquilarum (Eichler, 1943) and Colpocephalum impressum (Rudow, 1866) on the imperial eagle; and Degeeriella fusca (Denny, 1842) on the mars harrier were found for the first time in Turkey (25).

In the previous studies on long-legged buzzards (Buteo rufinus) in Turkey $(17,25,26,29)$, L.maximum, C. nanum, Colpocephalum sp., D. fulva and C. platystomus were detected. In the present study, long-legged buzzards were found to be infested with L. maximum, C. platystomus, D. fulva and C. nanum. Dik (19) reported Kurodaia fulvofasciata on a common buzzard (Buteo buteo) and Strigiphilus barbatus on the long-eared owl (Asio otus). In the present study, C. platystomus, L. maximum, D. fulva and C. nanum 


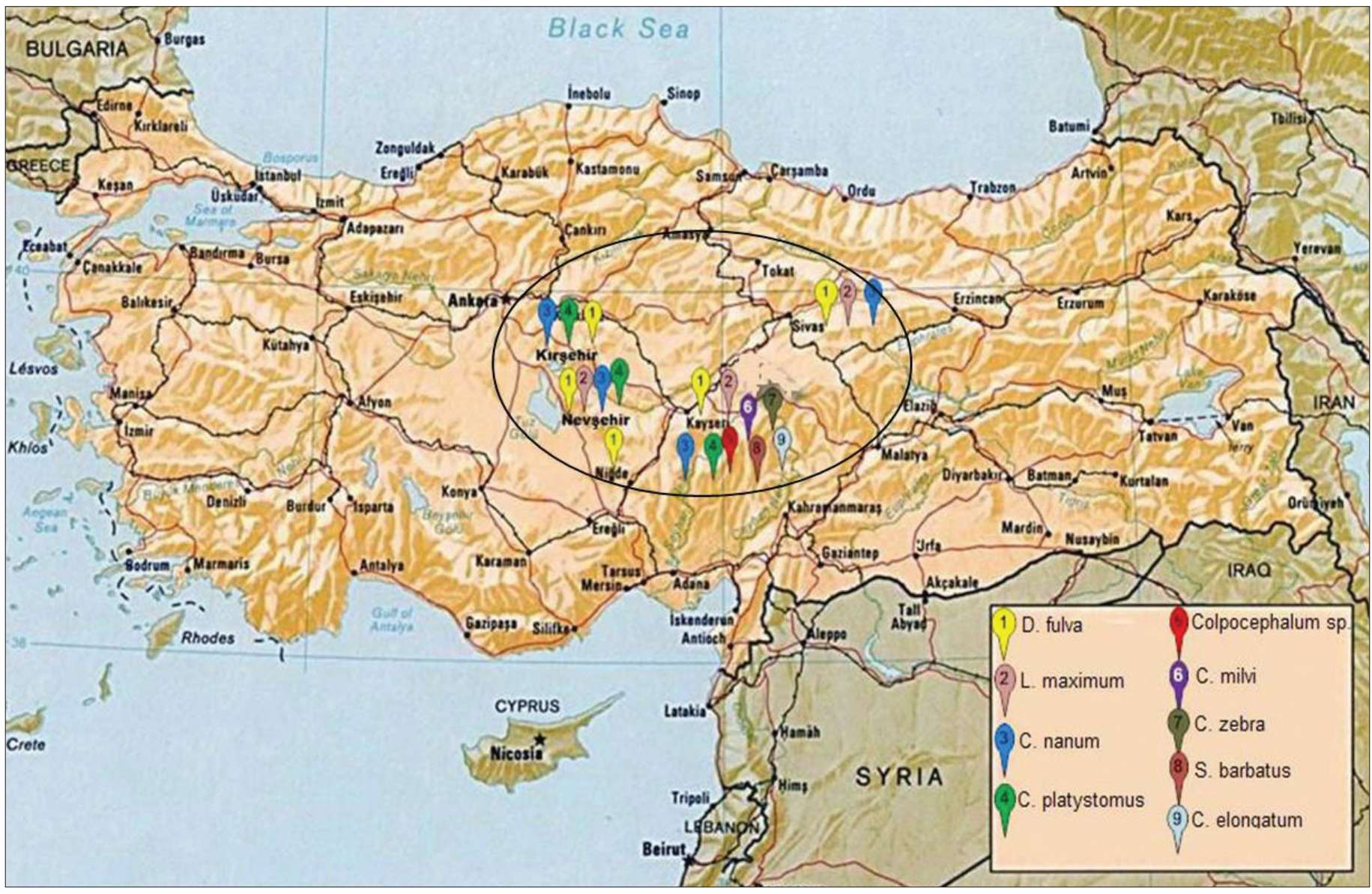

Figure 1. Distribution of louse species found on wild birds around Cappadocia

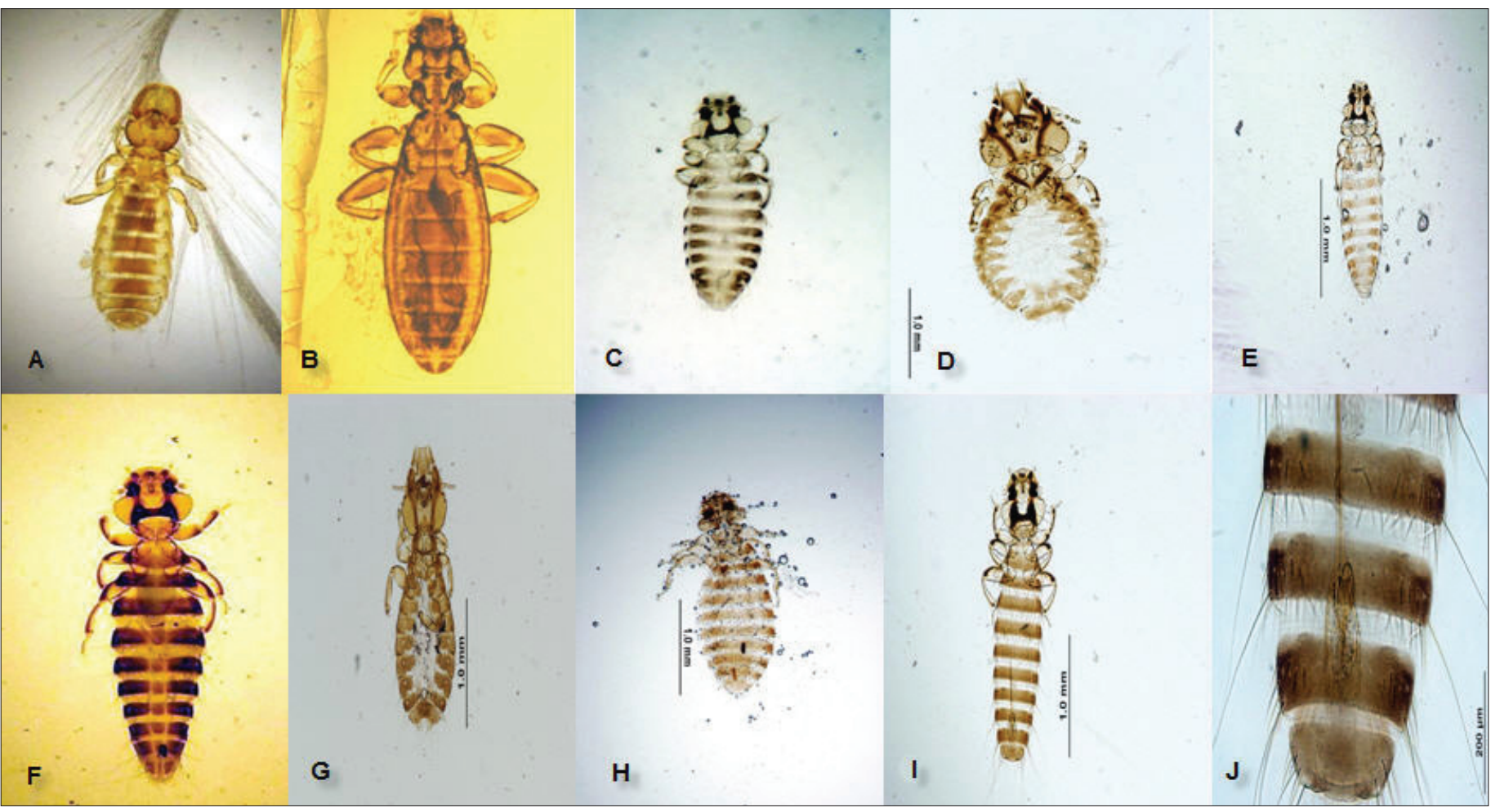

Figure 2. A) Degeeriella fulva (female), B) Laemobothrion maximum (male), C) Colpocephalum nanum (female), D) Craspedorrhynchus platystomus (female), E) Colpocephalum milvi (female), F) Colpocephalum zebra (female), G) Strigiphilus barbatus (female), H) Comatomenapon elongatum (female), I) Colpocephalum sp. male, J) Colpocephalum sp. male genitalia 
Table 1. Louse species collected from wild birds around Cappadocia region

\begin{tabular}{|c|c|c|c|c|c|c|c|c|c|c|c|c|c|c|c|c|c|}
\hline \multirow[t]{3}{*}{ Host } & \multirow[t]{3}{*}{ Location } & \multicolumn{15}{|c|}{ Louse species } & \multirow[t]{3}{*}{ Tota } \\
\hline & & \multicolumn{2}{|c|}{$\begin{array}{l}\frac{\pi}{\sqrt{0}} \\
\frac{0}{0} \\
\frac{1}{0} \\
0 \\
0 \\
0 \\
0\end{array}$} & \multicolumn{3}{|c|}{ 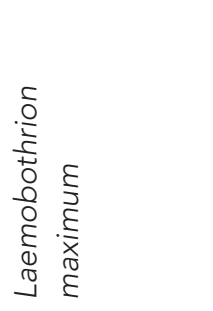 } & \multicolumn{2}{|c|}{ 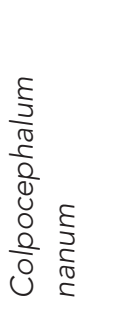 } & \multicolumn{3}{|c|}{ 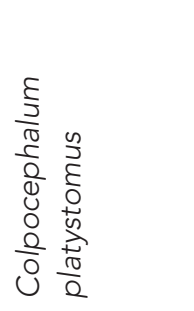 } & \multirow[t]{2}{*}{$\begin{array}{l}\dot{0} \\
0 \\
\frac{1}{3} \\
\frac{3}{0} \\
\frac{1}{0} \\
\frac{0}{0} \\
0 \\
\frac{0}{0} \\
0 \\
0 \\
0\end{array}$} & \multirow{2}{*}{ 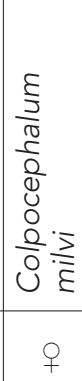 } & \multirow{2}{*}{ 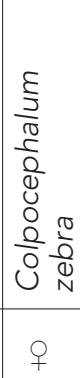 } & \multirow[t]{2}{*}{ 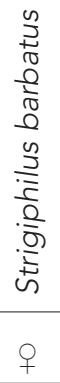 } & \multirow{2}{*}{ 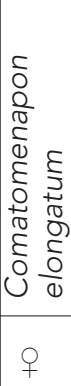 } & \\
\hline & & 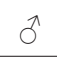 & $q$ & 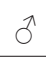 & q & $N^{*}$ & $\sigma^{\lambda}$ & q & $\sigma^{\pi}$ & q & $N^{*}$ & & & & & & \\
\hline \multirow{5}{*}{$\begin{array}{l}\text { Long-legged buzzard } \\
\text { (Buteo rufinus) }\end{array}$} & Nevsehir & - & 1 & 2 & 2 & - & 1 & 1 & - & - & 2 & - & - & - & - & - & 9 \\
\hline & Kayseri & 1 & 4 & - & - & 1 & 3 & - & 1 & - & - & - & - & - & - & - & 10 \\
\hline & Nigde & 1 & & - & - & - & - & - & - & - & - & - & - & - & - & - & 1 \\
\hline & Sivas & 2 & 2 & - & - & - & - & 2 & - & - & - & - & - & - & - & - & 6 \\
\hline & Total & 4 & 7 & 2 & 2 & 1 & 4 & 3 & 1 & - & 2 & - & - & - & - & - & 26 \\
\hline \multirow{5}{*}{$\begin{array}{l}\text { Common buzzard } \\
\text { (Buteo buteo) }\end{array}$} & Nevsehir & - & - & - & 1 & 1 & - & - & - & - & - & - & - & - & - & - & 2 \\
\hline & Kayseri & 2 & 4 & - & 1 & 1 & - & 2 & 1 & 3 & - & - & - & - & - & - & 14 \\
\hline & Kırşehir & 1 & & - & & & 1 & - & - & 2 & - & - & - & - & - & - & 4 \\
\hline & Sivas & 3 & 5 & - & 2 & 1 & 1 & - & - & - & - & - & - & - & - & - & 12 \\
\hline & Total & 6 & 9 & - & 4 & 3 & 2 & 2 & 1 & 5 & - & - & - & - & - & - & 32 \\
\hline $\begin{array}{l}\text { Black kite } \\
\text { (Milvus migrans) }\end{array}$ & Kayseri & - & - & - & - & 1 & - & - & - & - & - & - & 1 & - & - & - & 2 \\
\hline $\begin{array}{l}\text { Great egret } \\
\text { (Egretta alba) }\end{array}$ & Kayseri & - & - & - & - & - & - & - & - & - & - & - & - & - & - & 1 & 1 \\
\hline $\begin{array}{l}\text { Honey buzzard } \\
\text { (Pernis apivorus) }\end{array}$ & Kayseri & - & 1 & - & - & - & - & - & - & - & - & 1 & - & - & - & - & 2 \\
\hline $\begin{array}{l}\text { Long-eared owl } \\
\text { (Asio otus) }\end{array}$ & Kayseri & - & - & - & - & - & - & - & - & - & - & - & - & - & 1 & - & 1 \\
\hline $\begin{array}{l}\text { White stork } \\
\text { (Ciconia ciconia) }\end{array}$ & Kayseri & - & - & - & - & - & - & - & - & - & - & - & - & 1 & - & - & 1 \\
\hline TOTAL & & 10 & 17 & 2 & 6 & 5 & 6 & 5 & 2 & 5 & 2 & 1 & 1 & 1 & 1 & 1 & 65 \\
\hline
\end{tabular}

on common buzzards (Buteo buteo) and Strigiphilus barbatus on the long-eared owl (Asio otus) were determined.

\section{CONCLUSION}

Four louse species on the long-legged buzzard (Buteo rufinus), 4 on 14 common buzzards (Buteo buteo), 2 on the honey buzzard (Pernis apivorus), 2 on black kites (Milvus migrans), 1 on the long-eared owl (Asio otus), 1 on the great egret (Egretta alba) and 1 on the white stork (Ciconia ciconia) were found. The honey buzzard is a new host for Degeeriella fulva and Colpocephalum sp. and these lice were recorded for the first time in this study. In addition, Colpocephalum milvi from the black kite and Comatomenapon elongatum on the great egret were reported for the first time in Turkey.

\section{Conflict of Interest}

No conflict of interest was declared by the authors.

\section{REFERENCES}

1. Price RD, Hellenthal RA, Palma RL. World checklist of chewing lice with host associations and keys to families and genera. Price RD. Hellenthal RA. Palma RL., Johnson KP. Clayton DH. eds. The chewing lice: World checklist and biologicaloverview, Illinois Natural History Survey Special Publication 24, Champaign, Illinois, 2003; 1-448.

2. Hellenthal RA, Price RD. Phthiraptera (Chewing and suckin lice). Resh VH. Cavde RT. eds. Encyclopedia of Insects. 2nd edition, Elsevier, San Diego, 2009, p. 777-80.

3. Mimioğlu MM. Türkiye' de tavuklarda mallophagalar (tavuk bitleri) ve en uygun mücadele metotları üzerinde araştırmalar. Ankara Üniv Vet Fak Yayınları, No:32, Ankara, 1952.

4. Durden LA, Lloyd JE. Lice (Phthiraptera). Mullen GR. Durden LA. eds. Medical and Veterinary Entomology. 2nd edition, Academic Press, Elsevier, San Diago, 2009, p. 59-82.

5. Njunga GR. Ecto and haemoparasites of chickens in Malawi with emphasis on the effects of the chicken louse, Menacanthus 
cornutus. MSc. Thesis. Royal Veterinary and Agriculture University, Copenhagen, Denmark. 2003.

6. Sychra O, Harmat P, Literák I. Chewing lice (Phthiraptera) on chickens (Gallus gallus) from small backyard flocks in the eastern part of the Czech Republic. Vet Parasitol, 2008; 152: 344-8.

7. Cranston PS, Gullan PJ. Phylogeny of Insects. Resh VH. Carde RT. eds. Encyclopedia of Insects. 2nd ed. Elsevier, San Diego. 2009, p. 780-93.

8. Aksın N. The presence of chewing lice (Insecta: Phthiraptera) species on mallards (Anas platyrhynchos). 4th International Conference on Phthiraptera, Urgup, Cappadocia, Turkey,Türkiye Parazitol Derg, 2010; 34: 50.

9. Aksın N. The presence of chewing lice (Insecta: Phthiraptera) species on wild quails (Coturnix coturnix). 4th International Conference on Phthiraptera, Urgup, Cappadocia, Turkey, Türkiye Parazitol Derg, 2010; 34: 51.

10. Dik B, Şekercioğlu CH, Kırpık MA, Inak S, Uslu U. Chewing lice (Phthiraptera) species found on Turkish shorebirds (Charadriiformes). 4th International Conference on Phthiraptera, Urgup, Cappadocia, Turkey, Türkiye Parazitol Derg, 2010; 34: 36.

11. Gürler AT, Açıcı M, Erciyas K, Bölükbaş CS, Pekmezci GZ, Beyhan YE, et al. Menacanthus camelinus (Nitzsch in Giebel, 1874); First report from Lanius collurio (Passeriformes: Laniidae) in Turkey. 4th International Conference on Phthiraptera, Urgup, Cappadocia, Turkey, Türkiye Parazitol Derg, 2010; 34: 56.

12. Inci A, Yildirim A, Dik B, Duzlu O. Current knowledge of Turkey's louse fauna. 4th International Conference on Phthiraptera, Urgup, Cappadocia, Turkey, Türkiye Parazitol Derg, 2010; 34: 54.

13. Güralp N, Mayılmayıl A. Samsun'da sülünlerde (Phasianus colchicus) görülen sekal trichostrongylose ile mallophaga enfeksiyonlarının etken ve sağaltımları. Ankara Üniv Vet Fak Derg. 1971; 18: 271-5.

14. Tiğin Y. Ehli güvercinlerde (Columba livia) bulunan ektoparazitler. Ankara Üniv Vet Fak Derg. 1973; 2-3: 372-90.

15. Aksın N. The presence of mallophaga species on wild partridge in the Elazıg District. Turk J Vet Anim Sci. 2003; 27: 559-65.

16. Aksın N. Elazığ yöresinde yabani kazlarda bit enfestasyonu. Turk J Vet Anim Sci. 2004; 28: 87-90
17. Dik B. Mallophaga species on long-legged buzzards (Buteo rufinus): new records from Turkey. Türkiye Parazitol Derg, 30 2009; 226-30.

18. Dik B. Türkiye'de çoban aldatanlarda (Chabrimulcus europaeus L.) ilk Mulsiticola hypoleucus (Denny, 1842) (Pthhiraptera: Ischnocera) olgusu. Türkiye Parazitol Derg, 2009; 33: 212-4.

19. Dik B. Türkiye'deki evcil ve yabani kanatlılarda görülen çiğneyici bit (Phthriptera) türleri. Türkiye Parazitol Derg. 2010a; 34: 55-60.

20. Dik B. Chewing lice found on wild birds: New records from Turkey. 4th International Conference on Phthiraptera, Urgup, Cappadocia, Turkey, Türkiye Parazitol Derg, 2010; 34: 47

21. Dik B, Uslu U. The first recording of Piagetiella titan (Menoponidae: Mallophaga) on a white pelican (Pelecanus onocrotalus, Linneaus) in Turkey. Türkiye Parazitol Derg. 2006; 30: 128-31.

22. Dik B, Uslu U. Mallophaga (Insecta) species occurring on storks (Ciconia ciconia Linnaeus, 1758). Türkiye Parazitol Derg. 2006; 30: 220-5.

23. Dik B, Uslu U. Konya'da Halkalı sülünlerde (Phasianus colchicus) Cuclotogaster heterographus (Mallophaga: Lipeuridae) enfestasyonu. Türkiye Parazitol Derg. 2006; 30: 125-7.

24. Dik B, Uslu. Strigiphilus strigis (Mallophaga: Philopteridae) in a Eurasian eagle owl (Bubo bubo interpositus) in Turkey. Türkiye Parazitol Derg. 2007; 31: 69-71.

25. Dik B, Uslu U. Konya Hayvanat Bahçesi'ndeki Kanatlı Hayvanlarda Görülen Çiğneyici Bit (Amblycera, Ischnocera) Türleri. Türkiye Parazitol Derg. 2009; 1: 43-9.

26. Dik B, Ozkayhan M. Mallophaga species on long-legged buzzards (Buteo rufinus) in Turkey. Türkiye Parazitol Derg. 2007; 31: 298-301.

27. Dik B, YamaçE. First report of Colpocephalum trachelioti (Amblycera: Menoponidae) on a black vulture (Aegypius monachus L.) in Turkey. Türkiye Parazitol Derg. 2008; 32: 149-52

28. Dik B, Uslu U, Derinbay Ö, Işık N. Türkiye'de, sığırcıklarda (Sturnus vulgaris, L.) görülen bit (Phthiraptera; Ischnocera Amblycera) türleri. Türkiye Parazitol Derg. 2009; 33: 316-20.

29. Gülanber A, Kaya Ü, Vaassen EWAM, Yavuz E. Chewing-lice on longlegged Buzzard. Indian Vet J, 2006; 83: 1238-9.

30. Karataş A, Göçmen B, Karataş A. A new record for Turkish lice fauna: Dennyus hirundinis (Linnaeus, 1761) (Mallophaga: Menoponidae). Türkiye Parazitol Derg. 2008; 32: 77-8. 